\title{
Community-Based Art and Gentrification: A Bronzeville Story
}

\section{Gentrificação e Arte com Base na Comunidade}

\begin{abstract}
This text relates the observation of the ongoing changes in the evolving African American community of Bronzeville, Chicago and how community-based art can function as an asset in the recognition and development of its cultural foundation. Community-based art is defined as art that is by, for and about community members and their spaces, created with their participation. Gentrification is defined here as the renewal of a community that includes replacement of former residents of modest means with more affluent new residents. The text also suggests ways that community-based art can function as an agent for memory-keeping and future community development which includes the relevance of community members as knowledgeable arbiters involved in the rebirth of their historic spaces encourages the thoughtful process of cognitively and emotionally interacting with the art stories of other communities.
\end{abstract}

Keywords: Community. Gentrification. Art education.

Resumo: Este texto relata as observações das mudanças que estão ocorrendo no evoluir da comunidade afro-americana de Bronzeville em Chicago, USA, e de como a arte com base na comunidade pode funcionar como um bem de valor no reconhecimento e desenvolvimento a partir de suas fundações culturais. A arte com base na comunidade é a arte que é feita por, para e sobre os membros da comunidade e seus espaços criados com sua participação. A gentrificação é definida aqui como a renovação de uma comunidade que inclui a realocação de antigos residentes de meios modestos por novos de maior poder aquisitivo. O texto também sugere modos de como a arte com base na comunidade pode funcionar como um agente para manter a memória e os futuros desenvolvimentos da comunidade como árbitros do conhecimento envolvidos no renascer de seus espaços históricos, encorajando o processo reflexivo ao interagir cognitiva e emocionalmente com as leituras de arte de outras comunidades.

Palavras-chave: Comunidade. Gentrificação. Arte educação.

\section{Introduction}

W hen people know the power of their stories/narratives, how they are shaped and presented, and by whom, how they effect the quality of their present and future, it is possible for them to envision their role in creating the life that they want. And, as community members residing in spaces that have valued cultural personalities forged by time and circumstance, stabilizing and nurturing those communities is a worthwhile goal. Because of my regard for community processes and community voice, I am observing the ongoing changes in the evolving African American community of Bronzeville, Chicago and how community-based art can function as an asset in the recognition and development of its cultural foundation. I define community-based art as art that is by, for and about community members and their spaces, created with their participation. Gentrifica-

DANIEL, Vesta H. A. Community-Based Art and Gentrification: A Bronzeville Story. Informática na Educação: teoria e prática, Porto Alegre, v. 19 n. 1, p. 85-97, jan./maio 2016. 
tion is defined here as the renewal of a community that includes replacement of former residents of modest means with more affluent new residents.

Part of my approach employs historical narrative that describes the majoritarian view of phenomena that shaped Bronzeville and the counternarrative which expresses non-mainstream experiences or truths that are constructed through living. Since the Bronzeville story has an ever-growing online presence that serves as a narrator, I have turned to that resource to listen to the story about recent developments told from varying perspectives. In that respect, I am just a storyteller. By looking at Bronzeville's history, including the interests of stakeholders such as real estate developers, cultural activists, artists, entrepreneurs, homeowners, long-term and urban pioneer community dwellers, I will suggest ways that community-based art can function as an agent for memory-keeping and future community development. I turn to an assets-based approach to community building that includes the relevance of community members as knowledgeable arbiters involved in the rebirth of their historic spaces.

\section{Story Telling}

According to critical race theorists (DAIUTE; LIGHTFOOT, 2004, HUM; GUY; MANGLITZ, 2006) counternarratives or counter-storytelling express non-mainstream experiences. And, Collins and Daniel observe that

[...] [w] hen the stories about communities are missing, the information about how the communities work is missing, as well. [...] Furthermore, the cultural and social function of counternarratives is to demand social change by pointing out the collective stories of marginalized groups [...]. (COLLINS; DANIEL, 2014, p. 220)

Thus, recollecting aspects of my story/counternarrative is an act intended to make clear my perspective on the Bronzeville story.

I was born in Chicago, Illinois, in the United States Midwest. Chicago is a city of neighborhoods, which is a charitable way of saying that it is segregated by race and economic class. My parents were part of the second great northern migration of southern African Americans from 1940-1970. My family moved from difficult, tight living conditions in Chicago to a small home in a new African American community on Chicago's south side. As part of the many urban renewal projects that disrupted African American communities around the country, our community was physically destroyed by a new expressway, the construction of which slashed the area into deconstructed pieces. With a group of other black families, we moved to houses further south in Chicago, to a newly desegregated area. A police car was posted on our street. For months, until it seemed that racial violence against our families was no longer a threat, my younger, pre-school brother played ball with his personal policeman buddy. In 1966, when my sister and I were attending college, and my brother was approaching high school, Dr. Martin Luther King, Jr. brought his protest of segregation from the south to the north. He began in Chicago, known for its colonization of African Americans into slums, 
noting that it was the perfect place to start (JAMES, 2008). Following protests, demonstrations and race-based riots, the effect on housing discrimination was minimal. My family understood clearly that there were areas of the city in which we were not welcome. Thus, we abided by the unwritten rules of safety and mobility based on race. My parents, seasoned by their counternarratives of lived experiences in segregated southern towns and cities, were deft navigators through the sometimes dangerous path toward personal and collective uplift, freedom, opportunity and, community building. Through their small and large stories, they taught us to pay attention to how the components of geography, history, culture, politics, and race interacted to shape the city, nation and world.

My interest in community processes, or the community act (DANIEL; DREW, 2011), community-based art and, my personal relationship to Chicago motivate me to know more about how its future is developing. Although no longer a resident of Chicago, I continue to visit my siblings there. They are adroit in their navigation of the city and superbly observant of neighborhood aesthetics and politics as well as the cultural and economic push and pull endemic to communities experiencing the current wave of urban renewal and gentrification. They are knowledgeable community assets who introduced me to the ongoing Bronzeville process of transformation and self-identification. We focused on examples of community-based art as touchstones for measuring change. We looked for evidence of community voice as we engaged in random conversations, visited local businesses and interacted with art on the streets of Bronzeville.

\section{Bronzeville: Where the Narrative and Counternarrative Meet}

Clearly, lots of community members knew a little or a lot about the history of Bronzeville as an arts mecca. Thus, I was motivated to learn more about the Bronzeville story, as follows. Bronzeville (Black Metropolis-Bronzeville district) is a historic district in the Douglas community, south of the Loop (downtown) area of Chicago in Cook County, Illinois, United States. "Before it became Bronzeville its lush green boulevards and stately estates were home to some of Chicago's barons of industry and entertainment, such as the Swifts and the Marx Brothers" (BRONZEVILLE AREA RESIDENTS' AND COMMERCE COUNCIL, 2014). Formerly, known as the black belt, because of the African Americans who lived on this geographically narrow, belt like strip of land, it was later named Bronzeville to better reflect the color of African American skin. There are other communities called Bronzeville in other cities, as well. According to Chicago's Metropolitan Planning Council (2012), the neighborhoods that comprise Bronzeville are "[...] roughly bounded by $18^{\text {th }}$ Street on the north, $67^{\text {th }}$ Street on the south, the Dan Ryan Expressway on the west, and Cottage Grove Avenue on the east [...]" (METROPOLITAN PLANNING COUNCIL, 2012). Historically, it was a city within a city.

In order to escape the racism and oppression of the south, many African Americans came to the north seeking industrial jobs. Bronzeville received thousands of African Americans during the Great Migration between 1910 and 1920 and a second migration from1940-1970. In the 1940's Bronzeville was the "[...] second largest Negro city in the world [...]" (STANGE, 2003, p. xiii). Between 1916 and 1970, 
Chicago attracted more than 500,000 of the approximately 7 million African Americans who left the South during these decades. Before this migration, African Americans were 2 percent of Chicago's population; by 1970 they were 33 percent (CHICAGO HISTORY MUSEUM, 2007).

This Black Metropolis, like Harlem, New York, was the home of entrepreneurs, businessmen, entertainers, civil rights activists such as Ida B. Wells, millionaires, and the first black owned bank and insurance company. The arts flourished giving the world many creative geniuses including Pulitzer Prize recipient, Gwendolyn Brooks, jazz musician, Louis Armstrong and author, Lorraine Hansberry. There is a generous amount of homage paid to the creativity accompanying this migration found in the literary, visual, dance and musical arts.

While the historical essence describing Bronzeville seems consistent among formal and informal sources, there are varying descriptions of Bronzeville's boundaries, including the statement that it is a theme district with no geographic boundaries. Within those fluctuating boundaries are nine structures (eight buildings and one public monument) designated as Chicago landmarks on September 9, 1988. Of note is the 1936 bronze Victory Monument of an African American soldier added atop the original 1927 granite and bronze column and architectural setting. It "[...] honor[s] the achievements of the Eighth Regiment of the Illinois National Guard, an African American unit that served in France during World War I as part of the 370th U.S. Infantry [...]" (PUBLIC ART IN CHICAGO, 2009). This monument alerts us to the layered, nonlinear nature of the Bronzeville story. Indeed, it has tendrils leading in varying directions, one of which is the strange, racially charged story of the experiences of African Americans serving in the U.S. military.

During the Great Depression (1929-1939), the Works Project Administration's Federal Art Project (WPA-FAP) (1935-1943) created jobs for artists. A notable legacy of the more than 100 projects nation-wide intended to bring art into the every day lives of community members, is the South Side Community Art Center (SSCAC), dedicated in 1941. It is housed in a formidable stone building in Bronzeville. The SSCAC was the first black art museum in the United States (KNUPFER, 2006). As the only remaining WPA-FAP in the nation, and a Chicago Landmark, the SSCAC maintains its focus on the archiving, presentation and creation of art of African Americans. As I moved around the community, many paths lead back to the SSCAC and to the DuSable Museum of African American History which unites the art, history and culture of Africans and African Americans.

\section{Urban renewal and removal}

Due to city racial restrictions on where African Americans could live in Chicago, Bronzeville became overcrowded. By the 1950's, local officials designated the area as blighted using the following descriptors:

- Too many families crowded into buildings

- Average building more than thirty-five years old

- Schools, parking areas, and playgrounds needed

- Obsolete, unsafe street ordinance violations 
- Close to a blighted area

- Houses converted to commercial use

- Too many families moving away

- Growing decay of buildings

- Lack of building maintenance (URBAN..., 2014)

Moreover, because of the financial disinvestment following World War II, many Bronzeville businesses died. Many residents, who were financially able, moved further south in the city to newly racially unrestricted areas while still remaining in segregated pockets of the city. To address the housing shortage and slum conditions, the Chicago Housing Authority, removed much of the slum housing and constructed two large, multi-floor, high-rise housing projects referred to by some as prisons for the poor. In 1958, 3000 people moved into Stateway Gardens. In 2007 it was demolished due to crime and terrible living conditions. In 1962, Robert Taylor Homes, then the largest housing development in the country, was completed. The 28 indistinguishable high-rise buildings contained 4415 units and stretched for over two miles. Due to crime, violence and unlivable conditions, residents were moved out of the Taylor homes in 2005 preceding its demolition in 2007 (TAYLOR, 2014). Now the urban renewal and accompanying gentrification begins. Thus, the vertical landscape, partially identifying the Bronzeville area, was flattened to yield struggling storefront businesses, vacant lots, private homes, historic Victorian Era architecture and, Gothic, Romanesque and Queen Ann-style mansions. This cohort of elements was all within a short distance of beautiful city parks, internationally famous museums, a world-class university, a gorgeous lakefront and the heart of Chicago, the downtown loop area. Given this mixture of challenges and endowments, where do the desires, activism and aspirations of Bronzeville community members enter the process of self-describing and reconstructing their own community? And, how can community-based art help the community to illuminate the solid, meaningful connection between its past and its future? The process begins with taking a closer look at what the community has to offer residents and visitors.

\section{Asset-based community development (ABCD): Controlling what you see in the mirror}

Rather than focus on the deficiencies or needs of a community, I agree with the asset-based community development ( $A B C D$ ) approach to how a community can take control of its own image. It identifies the already existing strengths and assets that can meet the needs of the community and that can contribute to community improvement. Consequently, I subscribe to the definition of a community asset provided by The Community Tool Box, a service of the Work Group for Community Health and Development at the University of Kansas, which is

[...] anything that can be used to improve the quality of community life [...] [including] a person [...] physical structure or place [...] community service...a business that provides jobs and supports the local economy...[and] everyone [who] can provide knowledge about the community [...] (COMMUNITY TOOL BOX, 2014). 
I happened upon a fine example of a community-based asset in Bronzeville: the Milton Mizenberg Oakland Museum of Contemporary Art. It is not a traditional museum. Rather, Mizenberg, a self-taught, African American artist, converted his home and two nearby vacant lots into an outdoor sculpture garden. His totemic wood sculptures are described with pride by Bronzeville residents, who are not only aware of their presence and accessibility but they also know the story of Mizenberg's serious health challenges that were seemingly overcome by his continuing daily devotion to beautifying the community with his art. Other welcome discoveries, that were not part of the city-funded artworks, but were nevertheless familiar to Bronzeville residents, include old and new culture-based, painted, ceramic and photographic murals. Chicago is full of murals. Currently, for example, seven photomurals are being installed around Bronzeville by former resident and urban planning proponent, Chris Devins. The famous artists, musicians and writers depicted (e.g., the first is a 12-foot-by-26-photo of Nat King Cole playing a piano is already up) are intended to encourage people to think of arts and culture as synonymous with Bronzeville. Devins hopes that the murals will inspire more young people to build on the artistic history of the community (CHOLKE, 2014). Toward this end, I encourage careful consideration of The Wall of Respect mural (i.e., painted in 1969 and destroyed by fire in 1971), a monumental example of community consciousness. A very fine online presence, authored by Bautista, Chen and Foster-Rice (2000) including a few lesson plans. Other physical sites include a hand sculpted, walk-in, cement and mixed media shrine commemorating a deceased community member, community gardens, extraordinary building facades, street fairs and distinctive yard art.

Along the borderline space where community-based art merges into public-funded art is the art augmenting eleven blocks of Bronzeville's grandest boulevard, Martin Luther King Drive. The art and signage, as part of the City of Chicago Public Art Collection, is reflective of Bronzeville's unique history, and is celebrated as one of the most significant examples of the city collection. Notable among these works of artist created individualized public benches, lush landscaping, The Bronzeville Walk of Fame, The Victory Monument, and, the historical markers lining the boulevard, is the bronze 15 feet high sculpture by internationally renowned sculptor, Alison Saar, entitled Monument to the Great Northern Migration. The sculpture depicts a traveler facing north, carrying a worn suitcase, whose suit is made of shoe soles, and whose arm is raised in salutation. Marking the entrance to Bronzeville, the sculpture also symbolizes the development of the city of Chicago and post-Civil War America. It is easy to imagine how these artworks, as sources of knowledge, could stimulate formal and informal discussions and activities about their meanings as well as historical and archival efforts connected to personal, related collections of art and memorabilia possessed by community members.

And, finally, among the many other assets, is the monthly Bronzeville Art District Trolley, which is a guided tour of Bronzeville's art venues, such as well-established galleries, an art center, a museum and now the community-based Mizenberg Oakland Museum of Contemporary Art. However, when riding the trolley or taking a city bus ride, it is evident that Bronzeville is still a block-by-block area of contradictions: beautiful developments and assets juxtaposed to still blighted areas.

According to the Bronzeville assets map, created by the Chicago Grassroots Curriculum Taskforce Center, Bronzeville is commonly associated with the architecturally prescient "[...] Illinois 
Institute of Technology, University of Chicago, U.S. Cellular Field, [which is] the official stadium of the Chicago White Sox, and [the] Hyde Park home of President Barack Obama [...]" (CGCT BRONZEVILLE COMMUNITY TOUR, 2014).

The center notes that in order to include residential neighborhoods like Bronzeville as common tourism destinations, the authenticity of these places must be established. It should be noted also that previously the Bronzeville area appeared as a vacant space on Chicago maps. It did not exist from the point of view of Chicago tourism and history. Thus, based on residential insight about valued sites, the center created the Bronzeville Asset Map that includes public art, businesses, public institutions, residential insight comments, museums, centers and, landmarks. Of course, all of this activity is troubled by the question: who and what determines authenticity? Is it the majoritarian (i.e., white, monied) definition of charm and upward mobility? Or, is authenticity an artful depiction of community values reflected in safe, aesthetic, creative, historically vibrant spaces that are also charming and upwardly mobile?

In a different project sponsored by the Bronzeville Visitor Information Center (NIECIAK et al., 2008) a geodatabase of businesses, restaurants, landmarks of the community and public transportation yielded six aesthetically pleasing maps useful for tourism and community planning. Returning to the descriptor of Bronzeville as the Black Metropolis in Chicago, the nonprofit center intends to encourage a cross-cultural dialog at the local as well as the national and international levels and to develop Bronzeville as an international tourist destination. But, is tourism the only goal of Bronzeville residents? Is that the priority of the community or is it more the goal of long-time and new residents to require that the gaze of city officials include an understanding that the art and culture of the community are intrinsically valuable? Such an understanding can be demonstrated by city investment in the more dismal areas around the borders of Bronzeville that would include greater access to technology, art-making spaces, school improvements, bicycle paths, building and street repairs and late night activities for youth, such as midnight basketball.

Nevertheless, retail development, which is arguably fundamental to other, ancillary types of development, is the focus of various commercial and community development coalitions.

\section{Gentrification: Race still matters}

The changes in Bronzeville are significant. However, it is important to take a closer look at the nature of gentrification there. According to Badger:

In most U.S. cities the word [gentrification] has generally come to imply the gradual taking of a place from one group (usually poor people, usually minorities) by another (usually middle- or upper-class whites. (BADGER, 2012, s/p.)

As a consequence of gentrification over the past 14 years, median incomes and property values have soared in Bronzeville. However, this exemplifies a different kind of gentrification. There are still vacant lots and boarded up buildings that reinforce the unfortunate aspects of Bronzeville's narrative connected to poverty, crime and, violence, even if the perceived disorder is not real. And, 
Badger (2012) observes that although there are some white gentrifiers, atypically, the gentrifiers in Bronzeville are black returnees and residents who never left the community. Faye, for example, owner of Faie African Art in Bronzeville, never left the community. She described herself in a 2012 interview as a

[...] social worker in my soul, Africanist and gallerist, and long-term resident of what we call Bronzeville. [...] Bronzeville is a concept. It is not a location [...] [It is] interesting to talk to the elders about all of the wonderful black and bronze people who came out of here [...] all of the institutions. (DANIEL, $2012, s / p)$

Faye has created an elegant community asset. Her goal is to make extraordinary African art available to a wider audience, art that is usually seen only in private collections. In a 2012 interview with Faye she commented that folks who have never visited a museum or gallery come to her gallery and often return and stay for hours just to learn about the art under favorable, welcoming conditions. She gives them space with the objects, provides reference books, does not suggest that visitors are required to purchase anything and answers questions about the art, its presence in Bronzeville and discusses issues of concern to the community. The reason that Faye should not be considered to be gentry is that she is not interested in displacing residents of modest means. Instead, she is building collaboratively with them. She is interested in including them in defining a community space in which they are comfortable to live, work, learn and socialize. Hers is an inclusion strategy. However, Faye is working against the ongoing negative stereotyping of the community.

So, here is an interesting phenomenon. Hwang and Sampson (2014) conducted an expansive study of gentrification in Chicago. Using Google Street View, the researchers scoured thousands of Chicago streets for signs of gentrification. They found that neighborhoods that previously showed signs of gentrification such as financial investment in the area, continued to do so only if they were at least $35 \%$ white. If the neighborhoods were $40 \%$ black or more, the gentrification process slowed or stopped completely. "Bronzeville's historic 'blackness' - to borrow a term from the academics appears to overwhelm any sense of its identity as a neighborhood on the way up [...]" (BADGER, 2012). Clearly, race still matters.

\section{The Plan}

Due to its long history of Chicago Housing Authority (CHA) over-populated high-rises, Bronzeville carries a cultural burden that could affect the way it, and its residents, are perceived by Chicago residents. By disregarding its illustrious history as a creative and financially progressive community, emphasis is still placed on its problems rather than its potential. Thus, Bronzeville is a conundrum. Because it is located near the downtown area and the highly desirable shores of lovely Lake Michigan, a series of stately museums, parks and upscale shopping, it is still a city space worth coveting. Parts of Bronzeville are beautiful and ripe for an urban renaissance including self-definition supported by community-based art. 
Toward that end, current redevelopment of Bronzeville includes the opening of a 5.9 million dollar artists' lofts space in a 90 year old restored building that houses studios, a gallery, artists' apartments and an art incubator. Chicago mayor Rahm Emanuel states:

This project not only reinforces Bronzeville's legacy as a center for local artists and art patrons but it is proof that when the public and private sectors come together, cultural and economic vibrancy are possible (MAYOR'S PRESS OFFICE, 2014)

Also, according to Leroux and Grossman (2006), writers for the Chicago Tribune newspaper, a national trend in the restoration of communities is to include people who are poor in the mix of other community members with higher incomes rather than stigmatizing poor people as slum dwellers. The goal, they state, is to create economically diverse communities "[...] in which families can live over the generations, with grandparents renting affordable quarters close by the homes of their children and grandchildren [...]" (LEROUX; GROSSMAN, 2006, p. 8).

As part of this goal, the Chicago Housing Authority has created a Master Plan that

[...] proposes the development of over 1,300 units [...] [combining] affordable and market rate homeownership units with commercial/ retail space [...] and community amenities such as parks, schools, library, retail spaces (e.g., coffee house, bank, restaurant), a new police station and public transportation. Various phases were completed in 2005, 2006, 2008. Other construction is yet to come [...] (CHICAGO HOUSING AUTHORITY, 2014, s/p).

Such a plan provides opportunities for community visionaries and visualizers, including children and youth. In response to this opportunity, Candace, who is a local visual artist, water rights activist and art historian, also works with groups of children and youth from the Bronzeville area to create a mural project. She reviews the history of Bronzeville with the mixed age groups of children from a middle school and a state run group home for older children who are wards of the state. She notes in my 2012 interview with her:

Some just don't get it at all [...] [but] by the end of the session[s] they are in love and enlightened about how they can make their community better. Last week [I asked] [...] what are their feelings when they walk down $47^{\text {th }}$ street [in Bronzeville] now? And most of the feelings were negative feelings; fear, fright, being scared, looking like no one was there. Then one young man said: It looks like it's ripe for opportunity [...] And then [I asked] what did we think it looked like in 1950 [when it was a Black Metropolis]? [...] So they're doing a visioning kind of peace, they're looking to the future with how we still live on $47^{\text {th }}$ street and how we still make it [...] strong and livable [...].

They're always there [on Saturdays] when you tell them it's about them. This is your life [...] See, your future is big and looming and out there [...] so, how can we make it so that it is the best way that you want to live, not just how you can get by? [...] So, they're really starting to open up their eyes and their mouths and their minds and making some changes and looking at things a 
different kind of way. So, I'm getting some wonderful drawings and sketches from them [...] (DANIEL, 2012, s/p ).

\section{Conclusion}

Community-based art serves as a memory-keeper, meaning-maker and place-holder. It can assist community members in responding to and participating in phenomena accompanying gentrification such as liberatory imaging, community ethos, cultural agency, varying forms of resistance to and/or embrace of change. Should, then, educators, community members and students turn to community-based art as they conceptualize and address the relationship between community change (i.e., gentrification) and the ability to participate in shaping the community story? And, what are the varying perspectives on and creative activities addressing the significance of race as a contemporary phenomenon impacting the relationship of communities like Bronzeville to their host cities, like greater Chicago? Perhaps it is desirable for the responses to these questions to move considerations of community processes from rhetoric to action.

It seems that community action is always necessary. For example, during my current consideration of the Bronzeville story an 18-year-old African American young man, Michael Brown, was shot to death in his community in Ferguson, Missouri by a white police officer. The victim, who was shot a minimum of six times, was unarmed with his hands in the air in the universal position of surrender. The police officer had no connection to or investment in the victim's primarily African American community. The case is in the process of being adjudicated. The community is demanding justice and respect for its history and identity. Ultimately, an image generated by community members and seen on posters, buildings, Facebook walls, t-shirts and, videos is that of a silhouette of a man with his arms in the air accompanied by the words hands up, don't shoot. While the circumstances for the creation of this icon are agonizing, there is an accompanying opportunity for educators and students to explore the relationship between how meaning is attached to knowledge and how knowledge is constructed in community spaces. Moreover, community members, including educators, need to be prepared to address demeaning descriptions of themselves by others such as the poor and the powerless. Choosing to define themselves is an act of resistance important to foregrounding one's own story.

Finally, I suggest that community members can function as docents/curators of their own community-based art and art spaces. Indeed, school curricular material can contribute to the process of developing the cultural stories that surround the art in the Bronzeville community. To do so not only valorizes that particular art but it encourages the thoughtful process of cognitively and emotionally interacting with the art stories of other communities. 


\section{References}

BADGER, E. How Black Gentrifiers Have Affected the Perception of Chicago's Changing Neighborhoods: Two Chicago communities with similar stories see vastly different outcomes. In: CITYLAB. [S.I.]: The Atlantic Group, 2012. Available at: <http://www.citylab.com/housing/2012/12/how-blackgentrifiers-have-affected-perception-chicagos-changing-neighborhoods/4233/>. Acessed: $31 \mathrm{dec}$. 2012.

BAUTISTA, S.; CHEN, C.; FOSTER-RICE, G. The Wall of Respect on the Web. [S.I.: s.n.], [2000?]. Available at: <http://www.blockmuseum.northwestern.edu/wallofrespect/main.htm>. Acessed: 10 jun. 2015.

BRONZEVILLE AREA RESIDENTS' AND COMMERCE COUNCIL. History of Bronzeville. [Chicago], 2014. Available at: <http://www.thebarcc.org/history.php>. Acessed: 10 Jun. 2015.

CGCT BRONZEVILLE COMMUNITY TOUR. Bronzeville Asset Map. [Chicago], 2014. Available at: <https://depaul.digication.com/cgct_bronzeville_community_tour/Asset_Map>. Acessed: 10 Jun. 2015.

CHICAGO HISTORY MUSEUM. A Bronzeville Story. [Chicago], 2007. Available at: <http://greatchicagostories.com/bronzeville/background.php>. Acessed: 10 Jun. 2015.

CHICAGo hOUSING AUTHORITY. Park Boulevard. [Chicago], 2014. Available at: <http://www.thecha.org/pages/park_boulevard/50.php?devID=193>. Acessed: 02 mai 2014.

CHOLKE, S. Nat King Cole Mural Part of Man's Effort to Boost Bronzeville's Image. Chicago: DNAInfo, 2014. Available at: <http://www.dnainfo.com/chicago/20140812/bronzeville/nat-king-cole-mural-part-of-mans-effort-boost-bronzevilles-image>. Acessed: 21 May, 2016.

COLLINS, C.; DANIEL, V.A.H. Community curation as an alternative strategy for interpreting exhibitions. In: ACUFF, J.B.; EVANS, L. (Ed.). Multiculturalism in Art Museums Today. Lanham, MD: Rowan \& Littlefield, 2014. P. 211-231.

COMMUNITY TOOL BOX. Identifying Community Assets and Resources. Lawrence, KS, 2014. Available at: <http://ctb.ku.edu/en/table-of-contents/assessment/assessing-community-needs-andresources/identify-community-assets/main>. Acessed: 20 Jun. 2015.

DAIUTE, C.; LIGHTFOOT, C. (Ed.). Narrative analysis: Studying the development of individuals in society. Thousand Oaks, CA: Sage, 2004. 
DANIEL, V.A.H. Faie African Art Gallery in Bronzeville. [S.I.: s.n.], 2012. Unpublished raw data.

DANIEL, V.A.H.; DREW, D. Art education and the community act: An Inquiry into the interior of the process. In: YOUNG, B. (Ed.). Art, Culture and Ethnicity. $2^{\text {nd }}$ ed. Reston, VA: National Art Education Association, 2011. P.37-43.

HUNN, L.; GUY, T.; MANGLITZ, E. Who can speak for whom? Using counter-storytelling to challenge racial hegemony. In: ANNUAL CONFERENCE OF THE ADULT EDUCATION RESEARCH CONFERENCE, 2006, Minneapolis, MN. Proceedings. Minneapolis, MN: University of Minnesota, 2006. P, 224-250. Available at: <http//www.adulterc.org/Proceedings/2006/Proceedings/Hunn_et_al.pdf>. Acessed: 12 Jun.2015.

HWANG, J.; SAMPSON, R. Divergent Pathways of Gentrification: Racial Inequality and the Social Order of Renewal in Chicago Neighborhoods. American Sociological Review, v. 79, n. 4, p. 726-751, jun. 2014. Available at: <https://dash.harvard.edu/bitstream/handle/1/17615700/Hwang_Sampson_Gentrification_ASR_2014_Text\%20\%281\%29.pdf?sequence=3>. Acessed: 10 Ago 2015.

KNUPFER, A.M. The Chicago Black Renaissance and women's activism. Champaign, Ill: University of Illinois Press, 2006.

LeROUX, C.; GROSSMAN, R. Putting the 'Chic' Back in Chicago. Chicago Tribune, feb. 05, 2006. Available at: <http://articles.chicagotribune.com/2006-02- 05/features/0602050405_1_urban-pioneerscomeback-cities-paul-s-grogan/8>. Acessed: 10 Jun 2015.

MAYOR'S PRESS OFFICE. Mayor Emanuel Celebrates Opening of Bronzeville Artists Lofts and Marks One-Year of Chicago Neighborhoods Now Program. Chicago, 2014). Available at: <http:// www.cityofchicago.org/city/en/depts/mayor/press_room/press_releases/2014/jun/mayor-emanuel-celebrates-opening-of-bronzeville-artists-lofts-an.html> Acessed: 13 Jun. 2015.

METROPOLITAN PLANNING COUNCIL. Developing Vibrant Retail in Bronzeville. Chicago, Ill, 2012. Recommendation Report 2012. Available at: <https://www.metroplanning.org/uploads/cms/documents/mpc_developing_vibrant_retail_bronzeville_web.pdf>. Acessed: 12 Jun. 2015.

NIECIAK, J. et al. Mapping Community Assets in Bronzeville. [Chicago, Ill: Bronzeville Visitor Information Center, 2008?]. Available at: <http://gis.depaul.edu/shwang/CommunityOutreach/GEO242_ Service_Learning_Project/GEO242_Win1112_BVIC_BronzevilleAssetMapping.pdf>. Acessed: 12 Jun 2015.

PUBLIC ART IN CHICAGO. Bronzeville: Victory Monument. [Chicago, III], 2009. Available at: <http:// chicago-outdoor-sculptures.blogspot.com/2009/09/victory-monument.html>. Acessed: 10 May, 2015. 
STANGE, M. Bronzeville: Black Chicago in Pictures, 1941-1943. New York: New Press, 2003.

TAYLOR, R.R. Robert Taylor Homes. In: WIKIPEDIA: the free encyclopedia. [S.I., 2014]. Available at: <http://en.wikipedia.org/wiki/Robert_Taylor_Homes>. Acessed: 12 Jun 2015.

URBAN renewal and its implementation. [S.I.: s.n.], [2014?]. Available at: <http://www2.kenyon.edu/ Depts/history/projects/Pitts/implementation.htm>. Acessed: 12 Jun. 2015.

Submetido para avaliação em 14 de agosto de 2015.

Aprovado para publicação em 21 de janeiro de 2016. 